\title{
De-sacredizing of the Barong Dance Social Life in the Community Culture Bali
}

\author{
IGUSTINGURAHSUDIANA \\ Hindu Law Department, Faculty of Dharmaduta, State Institute of \\ Hindu Dharma Denpasar, Indonesia
}

\begin{abstract}
This article is the result of a research work in the village of Batubulan in 1998. In Batubulan there are two kinds of sacred barong which are given the title of Queen Gde Sakti and non-sacred Barong Tetamon for tourists' performance. The two barong have the same shapes but have different functions. The sacred Barong (Ratu Gde Sakti) serves to drive out or neutralize all the diseases that are unseen, while the barong tetamon's goal is to earn money. The sacred barong is housed at a place considered holy and sacred, being sacred on a particular day. While barong tetamon performs every day in the local stage without considering the good day, whether sacred or not. Tourists can watch the barong tetamon dance every day by paying the appropriate admission price that has been fixed by the owner of the stage. As a result of staging the many symbols and others, the sacred barong dance functions have changed their meaning when performed in the form of Barong Tetamon. De-sacralization processes have happened on various forms, e.g. the making, ceremonies, plays, the staging, staging time, and others. These changes are related to degrading the sacredness where there have been changes to the social meaning of barong dance. Due to changes in the meaning of it, it will slowly bring the cultural change of the society into a cultural market, particularly that of religion.
\end{abstract}

Keywords: De-sacralization, taksu, barong, and Rangda.

In the social structure of Balinese culture, barong dance is part of one form of cultural property arising from the elements of art. In conjunction with the community, the arts can be used as a medium to communicate a certain purposes by individuals or communities concerned. Likewise Barong dance it self can not be separated from the elements.

Barong Dance in its development can not be separated also from the influence of the structure of Balinese society both politically, economically and so forth. At the time of the kingdom, Barong dance is used by the king to convey ideas powers to the people of Bali. This occurs when the kingdom reached the peak of its power Kelungkung ie XVII century. At that time the kingdom of Klungkung structure is a decentralized unitary state structure (Sidemen, 1983: 6).

After the fall of the kingdom Gelgel April 27, 1908, then ruled by the Dutch in Bali. To power of the Dutch in Bali, Barong Dance is also used as media in the organization of banjar and sekaa/private to perform a sacred dance as entertainment to the tourists. As happened in the village of Moon rock found in four stages of barong dance performances for tourists. Viewing behavior of the people of Bali are so, then after the time of independence the government of Bali held sacred and profane art seminars in the field of dance in 1971 in Denpasar. The seminar was followed by five groups of society ie religious groups, traditional artists, government and tourism (Widja, 1983: 11).

Disagreement between the sacred and the profane in Balinese society, which continued with the implementation of the seminar led to the publication of the Governor of Bali No decision. Two years in 1973. It is a sacred ban on dance performances for tourists. Bali government ban does not make the stop of the tour manager of the group of artists and dance performances by modifying perform sacred dances to dance for tourists including barong dance. They then make copies of almost the same dance with the 
sacred dance. Duplicates dance is presented to the tourists.

Duplicates dance performances bring a result more and more dance blurring the differences between being sacred and profane. Then the increased competition dance profane sales to tourists. This is very clearly found in the Barong dance around Batubulan Village. In this village there are few places tetamon Barong Dance performances (for tourist consumption). So that competition between groups and organizations to seize market Barong Dance widened, it causes groups of people trying to promote and display similar barong dance Barong profane sacred with all its symbols, and full of ceremonial nuances made the sanctity. Competition is no longer tied to the sanctity of the Barong dance.

When a further note about the device and circulation Barong Dance performances in Batubulan profane, this can be said that the artists, community groups joined in the Barong dance organizations have an important role as a specialist in inerproduksi agents to sell the sanctity of the symbols barong dance to consumers of tourism. When viewed from Bourdieu's approach in "Towards a Sociology of Postmodern Culture" that the people of Bali who are members of the group performances at the Village Batubulan profane Barong, Barong Dance have sold the goods to be identified with the symbolic, marketing and demand conditions through the promotion of Barong dance. This is called the interest in the social sciences destablizing various symbolic interests of the existing hierarchy to produce a reclassification of the related field in line with their interests. This has already happened in the process desacredizing Batubulan's barong dance. Bourdieu's terms is called the "New Cultural Intermediaries” (Featherstone, 1993: 12) means in a global situation where the circulation flow and the information superhighway to help smooth the way change in the culture of sacred Barong dance which was originally closed, then the emergence of various channels of communication, needs, opportunities, under conditions of increasing competition, so desaredizing Barong dance becomes inevitable and community needs as it relates to the necessities of life.

This study uses qualitative case study approach, and analysis of single case with a single level of analysis, to find desacredizing barong dance is marked with a
Barong Dance performances for tourists in the four stages tetamon barong. The problem that this paper is how to form and meaning desakralisasi Barong dance in social and cultural life of Bali, especially in rural communities Batubulan.

\section{ORGANIZATION AND BARONG DANCE}

Barong dance associated with the organization of community life in Bali is enclosed by the Indigenous Village, Banjar, Pemaksan, and sekaa-sekaa (groupings). Each organization has its own criteria in determining the wheel of his organization. This means that the above organizations' traditional village has a genuine autonomy that is innate in the village since it was formed and recognized in the Dutch colonial administration as well as today after the country gained independence of the Republic of Indonesia “(Wirta Griadhi, 1985/1986: 2).

Autonomy possessed by the old traditional village that is changing since the issuance of No. 5 Year 1979. Government views with the issuing of such legislation is to achieve uniformity in the administration of government. Certain cases in the Indonesian villages is one of inhibiting the implementation of the unity government in the state of the Unitary Republic of Indonesia. Similarly, to strengthen governance and improve the ability of rural villages in the driving community participation in development administration in connection with the expanding village and effective (Marsono, 1980: 28).

Exit and entry into the force of the law is in the Balinese society have caused the village dual time traditional village (desa adat) and official village (provincial). Village offices is so great that its dominance of the traditional village traditional villages lose their autonomy and right to serve only as a functional village which is engaged in social religious and no longer is engaged in the administration. More fatally village must comply with all the customary rules issued by the village official.

In connection with the limited rights of the indigenous village autonomy movement is also very limited indigenous villages, ie engaged in religious social activities. Traditional village activities will be highly visible when going to perform religious ceremonies at a temple. In this implementation involves all the 
elements of traditional village organizations are below such as banjar, pemaksan and group.

In every village, banjar, pemaksan this, an organization that generally appears functional in character and engaged in various aspects of Balinese life called sekaa. There is bound by customary village and train there is also independent. Sekaa is still relevant to the customary village and banjar/ pemaksan serves to support the smooth-type activity sekaa tersebut.Jenis organization that still has something to do with aspects of traditional village life/banjar among others sekaa angklung, beleganjur, barong, baris, and other cak another.

The barong groups existing in the villages are traditionally managed. In Batubulan there are two, namely Sekaa Denjalan Batur and Barong Sekaa Tegal. Into the two, one is meant for tourists' attraction (tetamon). The sacred barong is placed in temples, and only performs when there is a Hindu religious ceremony in. While in the store two profane Barong at Temple Pererepan and placed together with the sacred Barong but in lower position.

The difference can be seen in terms of status and their respective organizational structures. Sekaa status and structure of the sacred barong organization under Indigenous Villages and Banjar, but profane barong group status is under pemaksan organization; not related to the indigenous villages. On his way sekaa Barong profane can take advantage of all facilities that are owned by sekaa sacred barong. In terms of space, facilities and infrastructure including the barong and mask performances are complementary. So although this sekaa differs in status and structure of organization, they are of complementary activities. This means that there is no conflict within each of these sekaa. When the barong dance performs in temples, the profane barong group does not interfere with the implementation of these performances. The profane barong activities continue to run in accordance with the program.

\section{History of Barong Dance in the Village Batubulan}

Village group of the sacred barong in Batubulan is estimated to have been in established in 1825, during the administration, I Dewa Agung Sakti in Klungkung. Artists danced to in the Kingdom of Calonarang Kelungkung (I Gede Yuda, Interview December 2, 1998).

In the meantime the profane barong group in Batubulan appeared around the year 1962. According to I Wayan Cebungan said that in the beginning of a tourism entrepreneur whose name I Wayan Fr Arsawan have barong stage in Tanjung Bungkak Denpasar. Because of difficulty finding a dancer so he came to embrace the Village which is located about one kilometer west of the village was still a territory Batubulan. Batubulan village, towns and villages clinch are limited by Bebengan river. On the arrival I Wayan Pater saw I Wayan Mide (character art in the clinch Kelod) and I Wayan Gara (character art in the clinch Kelod). The meeting produced an agreement to cooperate in performing sacred barong clinch a place in the village temple in the village of Barong Babian Kelod clinch. According to I Wayan Cebungan a Barong dancer who is still active at that time, foreigners who came to the clinch with a walk from the village across the river Bebengan Batubulan. The road is very narrow and there is no transportation, from the third discussion earlier figures, and then entered into a partnership with Batubulan castle figures, they included Batubulan village nobleman named Cok. Gede Agung. And the nobility outside the palace which is called I Dewa Gede Oka. This cooperation is to hold a barong dance performances at the Castle Batubulan. Barong, which was staged at that time is sacred barong from the clinch.

Barong performance at Castle Batubulan not last long because the new problems that tie up traffic flow direction of Denpasar, Karangasem. Then set the stage Sahadewa approximately 500 meters and the stage Batubulan castle. This stage is still managed by individuals who dipinpin by Dewa Wayan Oka. While in the village itself has sekaa Batubulan sacred Barong named sekaa Pemaksan Batur Den Road. Barong held sacred barong pemaksan is stored in the Pura Pererepan held at the Village Den Batubulan Village street. Use of this sacred Barong, usually danced in the Pura Dalem Taak every religious ceremony in the foundation.

According to I Nyoman Yuda (chairman of the Barong Denjalan Batur was still active) before the 
year 1967 barong performances were still awaiting orders from the existing travel agencies in Denpasar. Then after the year 1971 more and more orders came. A stage was built at the Batur Temple; another one was built in the courtyard of Pererepan 1975. Barong performances from then on were organized daily which used the sacred barong. After the 1975 imposition of barong Denjalan Batur temple made pererepan stage in the courtyard. Then the stage was still owned by the pemaksan barong; thus collective rather than individual management. This new stage of development was completed in 1975. The new staging of the barong has been daily. But the performances still used sacred barong. After the year 1978 barong tetamon group was established for commercially tourism goals. Then sacred barong is staged once in every three months' time, i.e. on the day of the full moon and on the day Kajeng Kliwon.

In 1978, the two groups of barongs, namely Den Road Sahadewa Batur and enter into an agreement to build a better stage given the stage name Puseh those far from the road about 500 meters to the east. This stage is completed around the year 1982. the use of this stage is rotated, each sekaa use during the week. In the year 1992 stood again a stage Puri Anom, one kilometer south of Stage Road Batur Den. This stage is managed by individuals purely business oriented. Stage collectively owned and managed banjar individual stage managed by the company (interview, I Wayan Cebungan, in His house of Banjar clinch, January 1, 1999).

Commercialization of the sacred barong dance as a performance for tourists started around the year 1920. As the year 1920, the Dutch intended to make the island into tourist destination because of the good living and a unique cultural community. For that reason Hotel Bali was established in Denpasar on that year, to accommodate European and American tourists. The tourists were transported by the Royal Dutch Shipping Company, (Koniklijke Pakketvaart Maatschappij) once a week from the sea port of Singaraja. (Widja, 1982/1983: 9).

Further development, more and more tourists coming to Bali and want to see the Barong dance directly. At that moment of embrace sacred Barong of Denjalan group, Tegaltamu, began enacting sacred barong dance to serve tourists using Calonarang play.
Performances took place until 1971. After that year Baring sacred performances are limited to a good day according to Hindu calendar calculation that day Purnama, Tilem and Kajeng Keliwon. This performances have nothing to do with the Hindu religious ceremonies the temple relating to customs or Banjar village. Similarly, the former with the theme ceritranya Calonarang since 1971 depicting Kunti Cerita Sraya.

Barong dance performances for tourists are what causes the existence of two in one Pemaksan sekaa Barong Barong, which is sacred Barong sekaa (Pemaksan Barong) and barong dance groups. Each group has different goals, such as sacred barong group is to the concern of the indigenous villagers when they organize a ceremony which is religious; and the profane group, barong tetamon is aimed at tourism entertainment commodities which are commercial.

\section{DESACREDIZING THE BARONG DANCE}

Barong Dance in the group dances are grouped into the sacred art or dance. This grouping is based on the results of the seminar "sacred and profane art" which was held in Denpasar in 1971, as a result of the discussions on the realities of the life Balinese arts and culture.

There were three kinds of art classification according to their functions. First, the trustee is the art which is used in performing a religious ceremony (Hindu) and is not warranted to be held outside of the provisions thereof. Second, bebali is the art which is used to support religious ceremonies (not compulsory). Third, Balih-balihan is the art which was held in conjunction with the appreciation of art and mere entertainment.

Thus Barong dance can be danced only / prepared in accordance with its function as an accompanist ceremony held on certain pretended to comply with the agreement of local Indigenous Village. But the reality in the Village Barong Dance Batubulan also staged for the tourists, although that use is barong tetamon (for tourist consumption) but sometimes also performed on the day sacred Barong Dance Kajeng Pon, Purnama and Tilem of Denjalan especially in the stage and the stage of Tegaltamu. 
In accordance with the concept of holy / sacred Barong dance in Batubulan then has undergone profane processes or commercialization so that various elements of the Barong dance has experienced desacredizing. This process as a thinking reality on the basis of social considerations and rationalism still put religion as a moral compass and can give meaning and human existence (Pradoyo, 1993, 89-94).

Sacred Barong performances for the benefit of tourists means that have led to the shifting values of the regions sacred Barong to the profane. Likewise tetamon Barong Dance performances by using the attribute or symbol that is almost the same as sacred Barong also means there has been desacredizing.

\section{Elements that desacredize of the barong dance}

\section{Barong mask-making process}

Making sacred Barong masks have to go through the process of socio religious, involving indigenous peoples who will come to have or that barong is holy or sacred will be made. Visible community involvement ranging from making the plan a meeting Barong, ceremonial wooden begging (nuwedin), pralina ceremonies (remove the wood and is considered normal sanctity symbolically), the ceremony makalin (early workmanship stage) and pasupati ngatep as well as the last rites.

Barong mask-making process while not as complete as making the profane sacred Barong. Barong profane on in the process there are two ways, namely by using a simple ritual nature and also can be purchased directly to barong maker Barong mask so that practically without ceremony.

Based on these stages will have occurred in desacredizing of the barong mask-making process occurs in the ritual and, executing a ritual. On the ritual use of sacred barong levels of primary and profane insult at the level of being small. While in the executive if there is a sacred indigenous village barong's level while the level of barong pemaksan which can be profane, or even personal.

\section{Main of ceremony of pasupati}

Pasupati of the barong ceremony in the Hindu community in Bali is the ceremony which includes the main level or even greater. So entitled in such ceremonies is to lead a priest called sulinggih. This is a holy person in the structure of the Balinese social stratum. He is trusted in his ability to lead the ceremonial start of the level of insult, intermediate and primary.

Meanwhile, in a ceremony led by Barong profane only a Stakeholder. Stakeholders have limited kewengan temple or a dependent territory of a relevant act, if the celestial universe (public temple), the broader authority but still lower than levels kewanangan and clergymen.

3. The process of making Barong ceremony Barong sacred ritualism consists of three levels, namely 1) prayascita and melaspas; 2). ngatep and pasupati; and 3). Ngerehin masuci and implemented by indigenous supporters of the barong and held at Pura Dalem.

Melaspas Prayascita ceremony and has the objective to remove stains that linger on and wear barong masks that will be sacred, so it is easy given the strength to live by a priest. Pasupati ceremony of ngatep and aims, to connect the head with his body. While the ceremony of mesuci or ngerehin, is aimed at testing the success of the ceremony pasupati i.e. whether the barong's supernatural powers are threre or not. The ceremony is complete by using neighbourhood relatives, namely Butuan's boar, sacred asoroh, daksina major in size, jerimpen pengamben, pejati on pelinggih deemed necessary. The implementation is selected on the day of Kajeng Kliwon, and is held at the Pura Dalem; and the sign of success is when the dancers become in trance.

Barong-making process profane ceremony only at the level prayascita done outside the Pura Dalem on stage or in the home owner stage. Prayascita ceremony aims to cleanse the stains are spiritually and pleaded taksu (magical power) so as to have danced attraction. There is also a barong sekaa tetamon who do not do anything against barong ritual that used to dance.

Ritualism elements making experience desakralisasi Barong Barong ie when the complete sacred ceremonies while using profane Barong ceremony only at the level of melaspas just do not even have to use in ceremonies. 
4. Barong Dance performances ritualism Before and after the sacred Barong Dance performances stakeholders always perform the ceremony as it has been established in accordance with religious literature. Bantam used before is a sacred Barong Dance performances by the great segehan, pejati, and penyambleh of a black chicken. Meanwhile, after staging sorohan offerings consisting of juice and pejati daksina and ending with wine and berem sprinkling the wine and mineral water (Interview, Jero Mangku Pererepan, at Temple Pererepan, Batubulan, December 2, 1998).

While in the staging Barong also used profane and sodaan pejati offerings. After this is offered, a small segehan is offered in front of the barong by using sebulu chicken. The rituals of the barong dance performances have also been experiencing desacredizing of a medium to a level that means less complete (i.e. the simplest).

\section{Barong Dance performances}

Barong Dance performances made without the play time when sandyakala (meetings between day and night) and midnight when the show Calonarang / put on the play. While the sacred Barong, which was staged for tourists in the stage and Denjalan Batur Tegal Reception is good every day, such as full moon (moon light), and Tilem Kajeng Pon (in death). Apart from these days, which was staged is Barong tetamon. Barong performances for tourists to walk every day except the day of Nyepi (warning saka turn of the year which takes place every year). When staging promptly at 9:30 pm until 10:30 pm every day. So when the Barong Dance performances has been in a shift experience that it was performed at the piodalan for the ceremony, at sandyakala and midnight; while the barong performances for the tourists are held any, mainly in the morning on a regular basis, or on requests or orders.

\section{Barong Dance performances Function}

Barong Dance performances functioned as a sacred) ceremonies accompanist who danced when no religious ceremonies sector in a temple; 2) against disaster, also related with the religious ceremony which falls on the Sixth sasih (the sixth month in December in Bali around AD) implementation called ngelawang; and 3 ). payer vows. While performing the functions Barong profane is merely served to tourists, not for the sake of the ceremony.
Barong Dance performances shift function which used to serve only for the sake of sacred religious ceremonies, now it serves the secular values that caused the removal of magical Barong religious for both itself and the views of society about the existence of sacred Barong.

\section{Supporting organization}

Supporting organization is a sacred Barong Indigenous Village. While the profane Barong organization there are two types of traditional organizations, which consisted entirely of local residents and organizations train company which consists of various series or a mixture of organizational and personal. In Stone Moon, traditional organization that engages in profane Barong Dance performances are pemaksan Denjalan Batur Tegal and Pemaksan Tegaltamu. While the personal is the barong Dance Stage and Stage Sahadewa Puri Anom.

The traditional Barong, the banjar's members of the local supporters, whose members are a combinations of barong group, gong or musical group, dance group, sekaa umbah, sekaa ornamental, sekaa payas and pecalang or security group. While in sekaa Barong private organization run by his supporters is Asita, Aspranata, Stage, sekaa barong, music, dance, decorations, section of transport, accommodation and promotion and security. Barong sekaa here is governed by a corporate leader or director.

\section{Performance Actor}

Conditions of becoming an actor in a sacred barong dance performances are:

a. Descent was chosen because according to indigenous people, descendants of the dance if it is getting there taksu (appeal).

b. Being able to dance that is meant is that although they are a descendant of Barong dancer, if not able to dance the descendants of the fact sought to dance.

c. No cuntaka; spiritually dirty because of the death of a family, by marriage (according to the Balinese, a three-day time limit before the bride was still considered a dirty / cuntaka).

d. Ngayah, meaning those who have the expertise Barong dance but not from seed. If agreed by the Indigenous Villages and they dare, then allowed ngayah or to serve (Barong dance volunteered as a backup dancer). 
e. Kahyangan, meaning they could unknowingly Barong dance well, although not by learning. Having realized / completed their dance again forgot the last dance techniques.

Whereas in the Barong Dance performances profane actor chosen to support the successful performance of two criteria i.e. depending on the stage is concerned whether the existence of traditional or individual. If the stage is still managed by such Pemaksan Banjar Banjar Banjar Tegal Denjalan Guest Batur and actors still use the traditional selection is based on descent, manners / members of the local train, one is required to join the nuclear family became sekaa barong. If they reject the right reasons like being a civil servant, was in school, college and so forth, then the row is not too binding. Descendants of residents of banjar is expected to help preserve this Barong Dance, except that if an actor from the seed according to some informants and traditions prevailing in the local community and dancing talents will be more attractive appearance (metaksu) because it is influenced by his father's blood. Barong Dance profane so that the quality can be maintained and more bestselling sold to tourists even without being promoted. The nature of this actor in the tradition of Balinese society called ngayahang system. Election actors on a stage-managed by the personal / private is not based on descent and ngayahang or serving system. The current system here is based on expertise / professionalism, the offspring is no longer a priority. Likewise, members of this stage is no longer only from the local train but already from various series, both from within the Moon Stone Traditional Village area or from outside, even from outside the district. Members of the stage is treated as employees of a company that all the rights and obligations become the responsibility of the stage director.

\section{Place of performance}

Barong performances are routinely performed sacred holy places like temples. While Barong profane staged at two locations namely at the temple and the stage that deliberately staging Barong.

Place Barong Dance performances have also been experiencing desacredizing namely that originally staged only in the sanctuary / place relating to the implementation of a Hindu ceremony, but now no longer the only gig at the shrine but made just outside the sanctuary at all to do with religious ceremonies.

\section{Ceritra / play}

Sacred Barong at first did not use the play was staged, but after King Gelgel want to staged at the palace, so there is a change from play to put on plays without the Calonarang story. This as a communication which is considered a tool in communicating religious ideas and the power of ideas

In the historical context after the Dutch colonial presence in Bali, the king no longer fully have the right to autonomy, however Barong Dance with Calonarang plays around the year 1825 is increasingly becoming popular. Staging is no longer dominated by the palace but by the Indigenous Villages, but coordinated by the royal family of Klungkung, led by the Dewa Agung Sakti. In its development in 1920, with the play Calonarang Barong Dance increasingly popular in the region, especially in the village of Gianyar clinch, Denjalan, Tegal Guest, Singapadu, Pejeng etc. (Wija, 1982: 18).

Whereas in the Barong dance performance that used to use profane plays Sraya Kunti story. These changes occur because of political change that is changing the status of work into the colonial government, from colonial to the republic of Indonesia, so that the court no longer has full authority on the development of dance, as well as the Indigenous Villages lose its existence in determining the direction of Barong Dance because of encouragement from the high social (Interview, I Komang Gede, in his home village Batubulan, December 1, 1998).

\section{Characterizations}

Inside the sacred Barong dance wear Calonarang play. But in its development, this play is turned into some version of 1) Katundung Ratna Mangali; 2) Marriage Bahula professor with Rachael Manggali; 3) Ngeseng Waringin (top struggle between the professor Bharadah with Calonarang); and 4). Kautus Rarung (Confirmation by Rachael Manggali Rarung about marriage with the King Airlangga).

In the ket sacred barong dance performances the play of Katundung Ratna Manggali is generally used, with characterizations as follows: 
a. Sisya carried out by four to six people, taking the role of Calonarang's students.

b. Matah Gede, a form of self-amendment of Calonarang with black practice.

c. Penasar, clown-servants as servants of King Airlangga.

d. Patih Madri and Maling Maguna, the trusted ministers of King Airlangga.

e. Manggali Ratna, daughter of Walunateng Dirah, and in story as the wife of King Airlangga.

f. Condong Matah Gede, attendant of Walunataneng Dirah.

g. Bondres, a comic character.

h. Barong, Master Bharadah embodiment.

i. Rangda, the embodiment Walunateng Dirah.

j. Kris Dancers, Barong's men who are under the barong's powers (being possessed).

While the characterizations in the staging of barong performance for tourists's entertainment around the stage in Batu Bulan Gianyar for the play Kunti Sraya performance, the figures are as follows:

a. Barong, a figure Sahadewa.

b. Apes as a forest animals.

c. Lady's maids of Dewi Kunti, two persons.

d. Dewi Kunti, as the main character.

e. Patih, Kunti's trusted man.

f. Rangda, as the figures of Durga/Goddess Durga.

g. Sahedewa, the savior figure of Goddess Durga.

h. Lord Shiva, the King of Gods character.

i. Kalika, black leader guard the tomb.

j. Pigs, the attendants of Goddess Kalika.

k. Bird, invisible character of Goddess Kalika.

1. Barong Keris dancers as followers of a trance.

The barong dance characterizations have also experienced desecration. The first is caused by the story or theme which has shifted from without act, to play the first role and then of Calonarang, to play Kunti Sraya's role. The shift in theme also causes a shift in the characterizations.

\section{Dance Structure}

The barong ket in Batubulan sacred dance has a structure in accordance with the general guidelines, namely pengawit, pengawak and pekaad without being followed by the staging of lakon. Wehereas, the barong ket dance for tourists' entertainment has the structure of pengawit or pengelembar and the play. The true barong dance is with three compositions or paileh, namely pepeson, pengawak and pekaad (Djayus, 1976: 50).

The sacred barong prioritize paileh or general guidelines of barong tetamon and time plays an important role for stage entertainment.

\section{The atmosphere magic or taksu}

The barong dance is considered sacred when it meets the criteria of the sanctity of the people of Bali. The barong must be ritualize or diupacarai with through pasupati, plaspas, ngerehin and so on. Then staging at the times of religious ceremonies and held at a certain site of a temple, or depending on the implementation of a ceremony. The magical atmosphere of the sacred barong dance performances is not only due to the time of staging, but also due to barong's mask-making process, rituals or ceremonies, storage, rituals conducted by the local people who become supporters of community of the activities. In addition, the practices of the sacred barong dance performances are always associated with the religious events in the temple's calendar.The kris dancers are always associated with mystical and magical stories, and are closely related to the implementations of the Balinese rituals.

In addition to the above, the magical atmosphere emitted by the sacred barong is the supporter of public views of the barong itself. People believe that their barong when will be able to function in a spiritual manner as a repellent of all diseases caused by evil spirits that interfere with human's physical and nonphysical types of lief. This view is closely related to the mythology that is strongly engrained in the community's mind concerning the Balinese barong which has become the symbol of messenger of god, namely God Brahma.

While the magical atmosphere that emanates from barong performances for tourists' entertainment is seen from attributes mounted when the dances are taking place. Most attributes used are religious in nature with slight changes, among others, the lelontek banners, umbrellas, rorob, kober, penjor, and staging venue which is in front yard of the Temple of Pererepan.

The peak of the magical atmosphere is seen from the staging of the barong for tourists entertainment from the last part of the scene, namely the appearance 
of the kris dancers who do the unying while pursuing the Rangda , because she trying to escape while the dancers try to stab her with kris or daggers. The atmosphere is very magical and sacred, particularly due to the staging of it at a temple.

The magical atmosphere of the sacred barong dance is due to the cumulative processes of the ritual activities conducted by community supporters, as well as views of the society in the a tradition of the mythology the barong. Barong is believed to function as a symbol of repellent-all epidemic diseases and to protect nature. from the disturbance evils. On the other hand, the fact that a kind of trance that occurs when the performance takes place either from the dancers of Rangda, Barong and kris by stabbing themselves daggers. In the end, the scene is ended when the holy water or tirta issprinkled with holy water (tirta) by the priest or pemangku.

Scenes and symbols that emit magical atmosphere in the sacred barong dance have been practiced also in Barong performances for tourists's entertainment. Magical scene between Rangda and Barong is discharge from the Temple of Pererepan, the emergence of a kris dancers who act full of trance stab themselves with a dagger, this scene is similar to the real trance scene in the sacred barong. The sprinkling of the holy water to the self stabbing act of the unying dancers who pretended to be in trance. Then the sacred symbols used during performances of sacred Barong and attributes to religious activities in a temple of banners, kober, penjor and so forth. In the staging of everyday like it is full to turn a pretense to manipulate the atmosphere and forms of sacred barong dance performances. Mimicking this as an attempt to sell the magical atmosphere to the tourists with purely commercial purposes. Manipulation of this staging whose function changes can lead to changing public opinion is also against the existence of a real sacred barong. Changes classify the existence as being similar to the same sacred barong with the barong for tourists' entertainment.

\section{SYMBOLS DESECRATION}

Dance is usually understood as a plastic art of visual motion. But beside that dance is the behavior of humans who have been prepared with a specific purpose, rhythmically and in terms of culture has the attitude patterns and gestures are not related to verbal performance in the motor activity. Inspired by selective stimulation from within oneself and the community environment. Dance translate into the meanings of the phrase through the manipulation of motion as an expression of dance established attitudes and values embodied by the basic beliefs of a person as part of the community, which depends on the pattern of their feelings and actions, all the elements of space and dynamics in unity rhythm combination and the consequences are not separate forms and styles of human behavior that produced it "(Tjintariani, 1989: 1).

Likewise the barong dance which is not created without it. This dance was born based on the complex cultural ideas and social conditions that support its emergence. Barong dance artists interpretation's creates religious integration with the context and environment community members as supporters. Barong Dance is full of meaning of the phrase, the recognized symbol of society as a tradition by the Balinese mythology. Symbolic meaning contained in the Barong Dance is an expression of artists who have become community property, for artists as part of society which serves the same culture with the group over the existing system and support structure of society, the Barong Dance has a meaning for the Balinese, like the meaning religious and secular meaning.

Faced with meaning, according Geerzt "should begin with a paradigm, that the sacred symbols used to synthesize a nation's ethos, namely, tone, characteristics and quality of their life, its moral and aesthetic style of their mood and their world view, namely picture they have about how to act, the ideas of the most comprehensive on the order. In the religious beliefs and practices, the ethos of a group of intellectually and make sense explained by describing as a way of life ideally adapted to the actual problems presented world's views. pressure meant here is how the meaning of the symbol related to the social order (Geerzt, 1992: 3-4).

Social event which is a symbol of the mood of a community group. Cultural actions, constructions, understanding and use of symbolic forms are social events like any other. 
When you notice about the Barong Dance with the symbolic in it can be interpreted as a culture that was born from the interaction of environment and social and religious orders in the Balinese culture. Barong dance is born with a religious background of the institutions that contains various communicative symbolic media which is mainly religious. Margaret Mead individuals' adaptation is connected to the outside world with communication process, as opposed to merely having the character reflexive response of the organism to stimuli from the environment (social behaviorism) (Johnson, in Lawang, 1986: 10).

Special characteristics of the human communicative symbol is that he is not limited to physical cues, instead he used the words, which sound symbols containing i-art i art together and are standard. Contrary to physical cues, sound symbols can be understood by those who use it in a way that practically the same as understood by others. Furthermore people can communicate with objects and their acts can be far beyond the boundaries of space and time. Then people can create a symbol which refers to the meaning of categories of an abstract universal; in which particular empirical objects is seen as an example of abstract categories; in which objects are classified. Short of human capability in using voice symbols adopted together, allowing the expansion and improvement of communication far exceeding what might be what the physical conditions alone. Indeed this ability that the world in which man lives is not just a physical world, that world is also a symbol of deconstructed world. It does not just include physical objects in short he is a world of culture (Johnson, in Lawang, 1986: 14-15). Symbols are attached to the figure in the Rangda in the barong dance. Barong is constructed on a whole as a cultural communication between supporters of the traditional village in Bali. Barong sin the community is considered as the sesuhunan or Lord. In the Hindu community in Bali, in communicating with the supernatural, the mythological God is the realization of Barong which associated with the God Brahma.

Interactions within the Hindu community in Bali with God, one of which appears in religious ceremonies. Religious ceremony and all its attributes is a symbol that is born of religious consensus in the community.
Religious symbols in the Hindu community in Bali, especially in the Batubulan area, Barong is very sacred. The sacredness is manifested by order of the tradition to the community invested in various media, both in art and other media. Media art recognized and exploited for the benefit goals, and they it sacred art due to attributes attached to it. In contrast, the art that does not get recognition or confirmation as being religious (jaust balih-balihan), as mere entertainment performing arts. In scientific terms is called the secular or profane. As a symbol of art profane action, attribute or magical symbolbound and those inherent in the art. If now in such a sacred art Balinese Barong dance performed for commercial purposes as art profane then indirectly all the symbols attached to the sacred dance is part of desecration in terms of good form, function, and meaning.

Socio-Cultural Meaning Barong Dance performances in Batu Bulan

Barong Dance Performances Barong Sacred and profane to cause a shift in market interest symbolic Barong dance itself. This means Barong dance which was originally as one of the sacred symbol, and then became profane yang symbol is identified with the merchandise. Balinese Barong staging one of the group in the village of Batubulan profane, has made a sale barong dance identified with symbolic items, marketing conditions and demand through the promotion of the Barong dance. Similarly, various processes of competition and monopolization, and various battles with Barong dance group that has been established with the new stand. Competition can be observed from the act of naming (naming), as one of the important strategies of various groups of Barong dance artists involved in fights with other groups and between Barong dance stage with the name on the board, the race using all the attributes and Another new term. This is called the interest in the social sciences as causing disturbance invarious symbolic interests of the existing hierarchy to generate a reclassification of the related field in line with the interests of their interests (Featherstone, in Prisma 1.tahun XXII No. 1993: 12).

Marketing staging Barong dance in Batubulan profane is a condition of society which can unwittingly blurring boundaries between barong dance and the sacred 
dance; to the profane in the art. This is referred to as a movement of social change in culture conditions, so that the authority of the sanctity of the previously retained, then changed adjusted to place, situation, condition (desa, kala, patra).

When observed more info on the device and barong dance performances of tetamon circulation, it can be said that the artists, community groups joined in the Barong dance organizations have a crucial role as the agents to sell the symbols sacred to the consumer Barong dance tourism. In a global situation where the circulation flow and fast-paced information to help smooth the way change in the culture of sacred Barong dance which was originally closed, then the emergence of a new communication channel, new demands, new opportunities, in conditions of increasing competition, so that no desecration Barong dance inevitable. Here is clearly visible among the artists who joined in the Barong dance performance as a seller profane symbols, with the perpetrators of the tourism economy as consumers symbol of mutual dependency between one another to meet the needs of tourists. That is the artist as a producer and seller of Barong dance symbol of tourism as a buyer while the perpetrators of the symbols.

Barong dance desecration seen in a variety of elements such as elements of the ceremony, master of ceremonies, the holder of the decision, staging, changes in organization, degrading of symbols, and so forth. Viewed from the glass eye postmodernism, this is what is called the mistrust on a single truth. In the era of postmodernism become plural and local legitimacy is not universal because there is no justice and Needs and single truth, because what is needed is justice and righteousness compound (Lyotard, 1979: 33 -34). Barong dance performances for tourists' interest is a breakthrough and a mirror have been waning status in religion and customs, as well as the ruling against him. Barong dance performance group has a view that tetamon barong dance performances are also a truth from the other side. This means that in making profane Barong performances in Bali, the public seems already to get the truth from tradition, norms, customs and culture of the Balinese.

In social life as well as staging Barong profane form of dynamism, meaning the artists and groups Barong dance performances have been doing business for renewal, experiment dance, so as to realize a Barong dance profane by giving the characteristic differences in the function of sacred Barong dance. Indeed subtly profane barong dance artists rejected the idea that is too totalitarian religion but combines dance with the sacred barong dance through symbolic processes in accordance with the real sacred barong dance. This is a form of rejection sensitivity in people of Bali to see the differences that exist both in the context of the activity as a cultural and religious supporters.

As the theory of pluralistic relativism of postmodernism that sees as one basis for assessing the truth of the reality of people's lives by looking at the truth of other theories that are still relevant, profane barong dance in Bali is a form of relativism in the community in terms of systems and structures existing in the Balinese culture

The scheme provides a description that in the Balinese Barong Dance is one of the cultural aspects of living and preserved. Barong dance associated with the system, norms, customs, the people of Bali. Barong dance vertically has undergone changes resulting from changes in the tourism economy, barong dance which was originally meant to have only a single monoauthority in the aesthetics of sanctity, now developed into a waiver of this authority, by displaying the profane Barong Dance in art house / stage-the stage along Moon Stone Village. Making art house as a response to the aesthetic needs to become profane by connoisseurs in the form of adaptation of the symbols of the sacred Barong dance. Such behavior of the Balinese people would be bringing a change of cultural resistance, which materialized in the form of spiritual desacredizing of the barong dance performances.

\section{CONCLUSIONS}

Changes from the sacred to the profane to a trust be categorized as a desacredizing. This happens at barong dance in public life Batubulan. Barong dance desacredizing signs can be seen from the four places tetamon barong performances around the village Batubulan, ie, the stage is Pemaksan Den Batur road, Sahadewa, Puseh, and Puri Anom. Formerly only on the attraction of the sacred barong when people do ceremonies / piodalan, but in the later development 
Barong in every day for the spectacle of attraction to tourists. Changes from dance guardian / sacred to dance balih-balihan/tontonan with the same attributes but the process, place, time performances have different goals desacredizing dance show as a barong. Desacredizing barong dance can be seen starting from the process of making barong mask, purification ceremony, when staging, barong function, where the staging, ritual performances, plays and characterizations, dancers, Barong storage and staging purposes, for barong tetamon no longer meet the requirements- sacred barong requirements. Staging sacred barong barong performances, while the spiritual purpose of all business-oriented tetamon for mundane needs. Here is already happening vagueness boundaries between the sacred and the barong barong tetamon in the Balinese social life, especially the people of Batubulan whose barong's taksu has indicated waning impact in people's lives. Thanks to the father of Heru Nugroho diucapakan, Mr. Raharjo, Mr. Bambang Udayana, Mr. Sunyoto Usman from Gajah Mada University, Yogyakarta.

\section{REFERENCES}

Djayus, I Nyoman, (1976), Teori tari Bali, Denpasar,Toko Guna Agung.

Gerzt, Clifford. (1992), Kebudayaan dan agama, Yogjakarta, Kanisius.
Griadi, I Ketut Wirta, (1980): Otonomi Desa Adat dan Kedudukannya Dalam tata Hukum Indonesia. Denpasar. MPLA Denpasar

Johnson, Doyle Paul, (1986) Teori Sosiologi Klasik dan Modern,Terjemahan, Robert.M.Lawang, Jakarta, Gramedia.

Lyotard, Jean Francis.(1979), The Post Modern Condition, a Report on Knowledge, University Press Of Minnesota Press, Mineapolis.

Marsono, (1980), Undang-Undang No 5 Tahun 1979, Tentang Pemerintahan Desa, Icthiar Baru Van Hoeven, Jakarta.

Tjintariani. (1989), Seni Tari suatu Tinjauan Sosiologi, dalam Rangka Menunjang Kebudayaan Nasional, Depdikbud Bali, Denpasar.

Pradoyo, (1993), Sekularisasi dalam Polemik, Pustaka Utama Grafika, Jakarta.

Sidemen, Ida Bagus. (1983), Sejarah Kelungkung: Dari Semara Pura Sampai Puputan, Kelungkung, Pemda Tk.II Klungkung, Klungkung.

Widja, I Gede. 1983, Album Of Bali, Ministry of Education and Culture Directorite, Genderan of Cultural Media, Jakarta. 